\title{
Multiple ecchymotic signs in acute pancreatitis
}

\author{
Rakshith N Murthy, ${ }^{1}$ Stalin Viswanathan, ${ }^{2}$ Dheeraj Jain ${ }^{1}$
}

${ }^{1}$ General Medicine, Indira Gandhi Medical College and Research Institute, Pondicherry, India

${ }^{2}$ General Medicine, JIPMER, Pondicherry, India

Correspondence to Dr Stalin Viswanathan; stalinviswanathan@ymail.com

Accepted 23 March 2020

\section{DESCRIPTION}

A 37-year-old plumber was admitted with acute abdominal pain of 4 days' duration that was associated with nausea, vomiting and constipation. He had consumed $\sim 120 \mathrm{~g}$ ethanol/day for the last 7 years and had been admitted for alcohol withdrawal syndrome 5 months ago. On examination in the emergency department, he had tachycardia (120 beats/min), normal blood pressure $(110 / 80 \mathrm{~mm} \mathrm{Hg})$ and tachypnoea ( 24 breaths/min). His abdomen was distended with ecchymotic discoloration of his left flank, lateral upper one-third of left thigh, the right inguinoscrotal area and bilateral calves (figure 1). Lipase was $391 \mathrm{U} / \mathrm{L}(<60)$ and contrast-enhanced CT of the abdomen revealed oedematous pancreas, peripancreatic fluid collection and mild ascites leading to a diagnosis of moderately severe pancreatitis. His other investigations were as follows: prothrombin time prolongation $7 \mathrm{~s}$, international normalised ratio 1.4 , platelet count $1.73 \times 10^{9} / \mathrm{L}$ $\left(150-450 \times 10^{9} / \mathrm{L}\right)$, fibrinogen $228 \mathrm{mg} / \mathrm{dL}(200-$ 400 ), total bilirubin $2.3 \mathrm{mg} / \mathrm{dL}$, aspartate transaminase $64 \mathrm{U} / \mathrm{L}$ and alanine transaminase $47 \mathrm{U} / \mathrm{L}$ and discriminant function of 34.1. Testing for activated partial thromboplastin time and D-dimer was unavailable in our institution at that point of time.

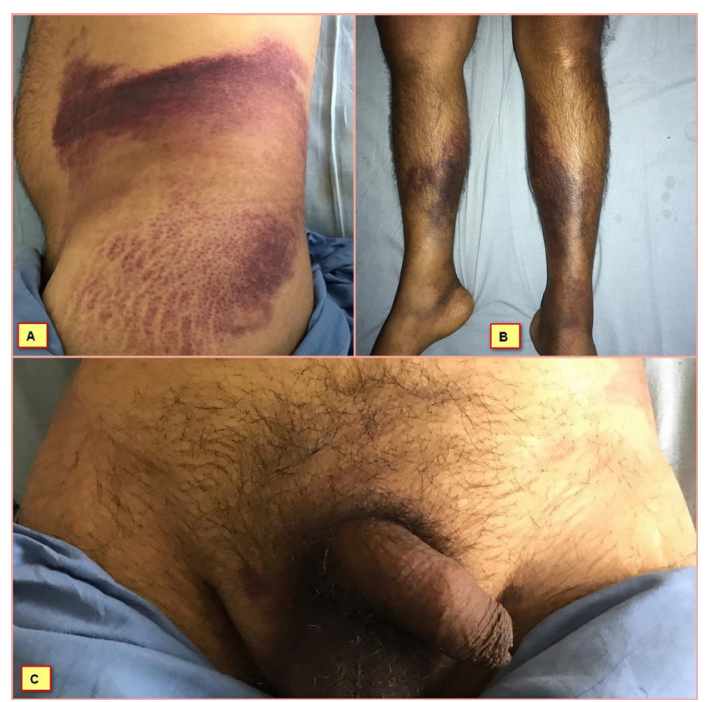

Figure 1 The ecchymotic eponyms: Grey Turner sign (lateral abdominal wall), Fox sign (lateral thigh discoloration) and Stabler sign (inguinal pubic region).

\section{Patient's perspective}

The doctors gave me a guarded prognosis in view of these red patches on the body, but I am so much relieved after the stay in hospital without developing a difficult-to-treat complication.

\section{Learning points}

- Abdominal ecchymotic signs do not always indicate internal haemorrhage.

- Multiple ecchymotic signs in pancreatitis appear to be uncommon.

- Eponyms help recollect infrequently observed signs and their associated disorders.

He was treated symptomatically with tramadol, pantoprazole, vitamin $B_{12}$, thiamine and intravenous fluids. He was able to tolerate oral fluids on day 3. By the seventh day, his ecchymotic patches began gradually fading and he was discharged on the ninth day of admission.

Ecchymotic eponyms involving the abdomen and groin include Cullen sign (periumbilical discoloration), Grey Turner sign (lateral abdominal wall), Stabler sign (inguinal pubic region), seatbelt sign and the Blue scrotum of Bryant. ${ }^{1}$ Fox sign indicates lateral thigh discoloration. These signs are usually indicative of a surgical or obstetric emergency such as a perforated duodenal ulcer or ruptured ectopic pregnancy. Our patient had three of these ecchymotic eponyms due to a medical disorder that was treated conservatively.

Contributors RNM: acquisition of images and writing. SV: writing and editing. DJ: literature search and design.

Funding The authors have not declared a specific grant for this research from any funding agency in the public, commercial or not-for-profit sectors.

Competing interests None declared.

Patient consent for publication Obtained.

Provenance and peer review Not commissioned; externally peer reviewed.

\section{REFERENCE}

1 Epperla N, Mazza JJ, Yale SH. A review of clinical signs related to ecchymosis. WMJ 2015;114:61-5. 
Images in...

Copyright 2020 BMJ Publishing Group. All rights reserved. For permission to reuse any of this content visit https://www.bmj.com/company/products-services/rights-and-licensing/permissions/

BMJ Case Report Fellows may re-use this article for personal use and teaching without any further permission.

Become a Fellow of BMJ Case Reports today and you can:

- Submit as many cases as you like

- Enjoy fast sympathetic peer review and rapid publication of accepted articles

Access all the published articles

Re-use any of the published material for personal use and teaching without further permission

Customer Service

If you have any further queries about your subscription, please contact our customer services team on +44 (0) 2071111105 or via email at support@bmj.com.

Visit casereports.bmj.com for more articles like this and to become a Fellow 